\title{
PELATIHAN PENGOLAHAN HASIL BUDIDAYA DAN PEMASARAN LELE SANGKURIANG UNTUK PENINGKATAN EKONOMI MASYARAKAT
}

\author{
Titi Suhartati dkk -Program Studi Akuntansi Keuangan Terapan \\ titi.suhartati@akuntansi.pnj.ac.id
}

\begin{abstract}
Abstrak
Kegiatan ini bertujuan untuk memberikan pembekalan terkait pengolahan dan pemasaran hasil budidaya ikan lele. Masyarakat komunitas peternak lele selama ini belum memahami mengenai pengolahan dan pemasaran produk olahan berbahan dasar ikan lele. Kurangnya pengetahuan dan pemahaman terkait hal tersebut menyebabkan penjualan produk lele terbatas hanya penjualan bahan mentah berupa ikan lele, padahal peluang untuk menjual olahan ikan lele sangat tinggi dan dapat meningkatkan pendapatan dari para peternak ikan lele. Kegiatan ini memilih objek pada komunitas ikan lele di desa Cijayanti-Bogor dengan peserta para calon peternak ikan lele di lingkungan wilayah tersebut. Pelaksanaan kegiatan diawali dengan melakukan survey dan pendekatan dengan komunitas peternak ikan lele. Kemudian pelaksanaan kegiatan dilakukan dengan memberikan pembekalan untuk pembuatan olahan produk ikan lele dan cara melakukan pemasaran. Kegiatan diikuti oleh 30 orang peternak dan calon peternak lele. Hasil kegiatan diharapkan para peserta memiliki pengetahuan dan pemahaman mengenai olahan dan pemasaran ikan lele sehingga dapat melakukannya untuk meningkatkan ekonomi keluarga dan masyarakat.
\end{abstract}

\begin{abstract}
This activity aims to provide debriefing related to processing and marketing of catfish farming. The community of catfish farmers has not yet considered the processing and marketing of processed products from catfish. The lack of knowledge and understanding related to this caused the sale of catfish products is limited for sale of raw materials in the form of catfish, whereas the opportunity to sell processed catfish was very high and could increase the income of catfish farmers. This activity selects objects in the catfish community in the village of Cijayanti-Bogor with participants from prospective catfish farmers in the area. The activity starts with conducting a survey and approach with the catfish farmer community. Then the implementation of activities is carried out by providing training of processing and how to sell catfish products. The activity was attended by 30 farmers and prospective catfish farmers. The results of the activity are expected that participants have the knowledge and understanding of the processing and marketing of catfish that they will improve the family and community economics.
\end{abstract}




\section{PENDAHULUAN}

Usaha pengembangan perikanan rakyat khususnya lele dimaksudkan untuk meningkatkan pendapatan dan taraf hidup nelayan dan memajukan kehidupan masyarakat. Peluang usaha budidaya ikan lele merupakan salah satu peluang usaha yang cukup diperhitungkan saat ini. Permintaan ikan lele semakin tinggi di pasaran dan membuka potensi peluang bisnis yang cukup menjanjikan.

Seiring perkembangan ekonomi dan majunya teknologi dengan pesat, maka makin berkembang pula sasaran dan tujuan yang akan dicapai oleh organisasi atau perusahaan yang akan menyelenggarakan suatu kegiatan. Setiap perusahaan dituntut untuk selalu tetap menjalankan usahanya serta menata manajemennya dengan baik. Adapun tujuan dari perusahan itu sendiri adalah mempertahankan kelangsungan hidup untuk perkembangan dan memperoleh laba.

Pemasaran adalah proses penyusunan komunikasi terpadu yang bertujuan untuk memberikan informasi mengenai barang atau jasa dalam kaitannya dengan memuaskan kebutuhan dan keinginan manusia. Proses dalam pemenuhan kebutuhan dan keinginan manusia inilah yang menjadi konsep pemasaran. Mulai dari pemenuhan produk (product), penetapan harga (price), pengiriman barang (place), dan mempromosikan barang (promotion),Pemasaran berjenjang adalah strategi pemasaran di mana tenaga penjual (sales) tidak hanya mendapatkan kompensasi atas penjualan yang mereka hasilkan, tetapi juga atas hasil penjualan sales lain yang mereka rekrut. Tujuan dari pengkombinasian empat bidang di atas disertai bidang lainnya adalah agar barang dan jasa yang di hasilkan berkualitas, tahan lama dan terjangkau oleh konsumen.

Di salah satu wilayah di Katulampa Bogor terdapat komunitas masyarakat budidaya ikan air tawar khususnya ikan lele sangkuriang. Selama ini hasil penjualan masih menggunakan cara konvensional meski zaman sudah menginjak era digital. Peluang bisnis ikan lele sangat menjanjikan. Mulai dari budidaya ikan lele, jual beli benih lele, dan bisnis olahan ikan lele. Namun, sukses dan tidaknya sebuah usaha tergantung dari ketekunan para pelaku usaha serta strategi pemasarannya juga. Berbagai cara \& strategi pemasaran ikan lele baik manual konvensional maupun online dapat diperoleh dengan mendapatkan pendidikan training pemasaran online / internet marketing.

Melalui kegiatan pengabdian masyarakat prodi D4 akuntansi PNJ, diharapkan dapat meningkatkan kualitas perekonomian khususnya kepada masyarakat setempat sebagai mitra kegiatan melalui pelatihan strategi maupun manajemen pemasaran hasil budidaya ikan lele.

\subsection{Permasalahan Mitra}

Mitra masih menggunakan cara konvensional dan belum memahami strategi dan manajemen pemasaran hasil budidaya ikan lele sangkuriang yang dapat meningkatkan kualitas ekonomi masyarakat setempat.

\subsection{Solusi dan Target Luaran}

Kegiatan pengabdian kepada masyarakat diawali dengan menentukan permasalahan yang terjadi dalam lingkungan masyarakat yang dipilih menjadi objek penelitian. Berikut permasalahan, solusi dan target luaran kegiatan ini.

\begin{tabular}{|l|l|l|}
\hline \multicolumn{1}{|c|}{ Permasalahan } & \multicolumn{1}{|c|}{ Solusi } & \multicolumn{1}{c|}{ Target Luaran } \\
\hline Mitra belum & Memberikan & Mitra dapat \\
memahami strategi & pemahaman & memahami dan \\
dan manajemen & tentang teknik & mempraktekan \\
pemasaran hasil & strategi dan & strategi dan \\
budidaya ikan lele & manajemen & manajemen \\
sangkuriang yang & pemasaran hasil & pemasaran hasil \\
dapat & budidaya ikan & budidaya ikan lele \\
meningkatkan & lele sangkuriang & sangkuriang yang \\
kualitas ekonomi & yang dapat & dapat \\
masyarakat & meningkatkan & meningkatkan \\
setempat. & kualitas & kualitas ekonomi \\
& ekonomi & masyarakat \\
& masyarakat & setempat. \\
& setempat. & \\
\hline
\end{tabular}

\section{METODE PENGABDIAN}

Metode yang digunakan dalam pelaksanaan program Iptek Bagi Masyarakat Berbasis Program Studi terkait dengan tahapan atau langkah-langkah dalam menyelesaikan solusi dari permasalahan mitra kegiatan.

\begin{tabular}{|l|l|}
\hline \multicolumn{1}{|c|}{ Solusi } & \multicolumn{1}{c|}{ Metode Pelaksanaan } \\
\hline $\begin{array}{l}\text { Memberikan } \\
\text { pemahaman } \\
\text { tentang strategi dan }\end{array}$ & $\begin{array}{l}\text { Pelatihan tentang bagaimana } \\
\text { strategi dan manajemen } \\
\text { pemasaran hasil budidaya ikan }\end{array}$ \\
\hline
\end{tabular}




\begin{tabular}{|l|l|}
\hline manajemen & lele sangkuriang yang \\
pemasaran hasil & mempunyai potensi ekonomi \\
budidaya ikan lele & masyarakat setempat Pelatihan \\
sangkuriang yang & dalam bentuk ceramah dan \\
dapat & praktik serta dilanjutkan \\
meningkatkan & dengan konsultasi serta \\
kualitas ekonomi & pendampingan. \\
masyarakat & \\
setempat & \\
\hline
\end{tabular}

Dengan metode pelaksanaan tersebut dapat dijelaskan secara terinci tahapan atau langkahlangkah dalam program ini.

\begin{tabular}{|c|c|c|}
\hline $\begin{array}{l}\text { Metode } \\
\text { Pelaksanaan }\end{array}$ & Kegiatan & Peserta \\
\hline \multirow{4}{*}{$\begin{array}{l}\text { Pelatihan } \\
\text { dalam bentuk } \\
\text { ceramah dan } \\
\text { praktik dan } \\
\text { dilanjutkan } \\
\text { dengan } \\
\text { konsultasi serta } \\
\text { pendampingan }\end{array}$} & $\begin{array}{l}\text { Persiapan } \\
\text { pendahuluan } \\
\text { untuk } \\
\text { merencanakan } \\
\text { kegiatan di } \\
\text { tingkat prodi }\end{array}$ & $\begin{array}{l}\text { Ketua tim } \\
\text { pengabdian, } \\
\text { KPS, dosen } \\
\text { prodi }\end{array}$ \\
\hline & $\begin{array}{l}\text { Kunjungan } \\
\text { persiapan } \\
\text { pelaksanaan } \\
\text { kegiatan } \\
\text { melalui } \\
\text { wawancara dan } \\
\text { observasi untuk } \\
\text { menganalisis } \\
\text { permasalahan } \\
\text { mitra. }\end{array}$ & $\begin{array}{l}\text { RT/ RW } \\
\text { setempat, } \\
\text { perwakilan } \\
\text { masyarakat. }\end{array}$ \\
\hline & $\begin{array}{l}\text { Pelaksanaan } \\
\text { pelatihan dalam } \\
\text { bentuk ceramah } \\
\text { dan praktek. }\end{array}$ & $\begin{array}{l}\text { Masyarakat } \\
\text { salah satu } \\
\text { kampung di } \\
\text { Katulampa } \\
\text { Bogor. }\end{array}$ \\
\hline & $\begin{array}{l}\text { Evaluasi } \\
\text { kegiatan }\end{array}$ & $\begin{array}{l}\text { Tim } \\
\text { pengabdian, } \\
\text { perwakilan } \\
\text { mitra/ } \\
\text { masyarakat } \\
\text { setempat }\end{array}$ \\
\hline
\end{tabular}

\section{HASIL DAN PEMBAHASAN}

Kegiatan pengabdian kepada masyarakat telah dilaksanakan pada tanggal 19 September 2018, dengan dihadiri oleh 30 peserta dari warga setempat dari Desa Cijayanti yang merupakan komunitas peternak lele. Kegiatan ini juga dihadiri dan dibuka oleh pejabat Desa dan RW setempat.
Kegiatan dilaksanakan pada komunitas peternak Lele Sangkuriang dengan mengambil lokasi di Desa Cijayanti, Babakan Madang-Sentul, Bogor. Lokasi ini merupakan tempat peternakan Lele Sangkuriang milik salah seorang peternak lele yang dianggap telah berhasil membudidayakan Lele Sangkuriang dan menjadi penggerak peternak lele lainnya dalam membududayakan lele.

Kegiatan dimulai dengan beberapa sambutan dari Ketua Jurusan Akuntansi-Politeknik Negeri Jakarta dan dilanjutkan oleh Kepada Desa Cijayanti serta Ketua Pelaksana. Kegiatan telah disusun dengan mempertimbangkan ada beberapa materi kegiatan yang disampaikan sehingga dalam kegiatan awal acara mengenai pembekalan pertama mengenai proses budidaya lele dilakukan oleh pembicara (Ibu Susi) yang merupakan praktisi peternak Lele Sangkuriang yang sudah berhasil dan sudah memiliki pengalaman dalam memberikan pelatihan terhadap para calon peternak lele.

Materi tersebut membahas, antara lain: pengetahuan mengenai jenis lele, persiapan dalam melakukan ternak lele, makanan lele yang berkualitas termasuk vitamin atau suplemen lele, jenis kolam peternakan lele yang memadai dan sehat untuk lele, lingkungan yang harus disiapkan dalam beternak lele dan pemanfaatan hasil ternak lele.

Kemudian setelah selesai kegiatan pembekalan dilakukan praktik di lapangan dimulai dengan membuat kolam lele dengan peralatan penunjang yang sudah tersedia. Pembuatan kolam lele membutuhkan peralatan yang sesuai dengan jenis dan kuantitas lele. Selanjutnya melakukan praktik pemberian makanan lele dengan cara-cara yang sudah diatur, baik jenis dan kualitas makanan, jarak waktu pemberian makanan, cara pemberian dan kuantitasnya. Praktik ini penting untuk mencegah kesalahan dalam pemberian makanan lele sehingga berakibat kerugian. Praktik ini merupakan pembekalan bagi calon peternak lele sehingga secara langsung dapat berinteraksi dengan pembicara dan melakukan secara langsung proses persiapan sampai proses pemberian makanan lele.

Selanjutnya dilaksanakan kegiatan pembuatan olahan makanan dari lele, berupa Otak-otak. Nugget dan Siomay berbahan lele. Hasil olahan ini dapat dijual oleh calon peternak lele selain dari lele yang belum diolah. Upaya ini bertujuan untuk dapat meningkatkan perekonomian para peternak lele terutama ibu-ibu. 
Hal ini terjadi karena para peternak lele sebagian besar adalah bapak-bapak sedangkan ibu-ibu jarang dilibatkan dalam proses peternakan lele. Dengan adanya pembekalan olahan dengan bahan dasar lele maka diharapkan terjadi sinergi antara para peternak lele dalam penjualan produk lele baik mentah maupun bahan jadi siap dimakan. Dalam kegiatan ini tim telah menyumbangkan beberapa peralatan yang terkait pengolahan dengan bahan dasar lele dan diserahkan kepada Pejabat Desa dan wakil dari peternak lele.

Kegiatan berikutnya adalah pembekalan terkait pemasaran dilakukan oleh pembicara kedua (Ibu Tetty Rimenda) yang merupakan pakar pemasaran. Materi yang disampaikan terkait pengemasan (packaging) dan merk. Dalam memilih kemasan diperlukan pengetahuan dan pemahaman terhadap kualitas dan jenis kemasan. Kemasan tergantung dari bahan yang dijual. Harus dipertimbangkan juga masa berlaku (kadaluarsa) makanan atau olahan yang dikemas. Terkait merk harus dipertimbangkan pemilihan merk yang mudah diingat oleh masyarakat dan bukan merupakan kata atau informasi yang memiliki konotasi negatif di masyarakat. Pemilihan merk sangat penting dalam upayan memasarkan suatu produk. Diharapkan dengan kemasan dan merk yang memadai, hasil olahan lele dapat dijual kepada masyarakat dengan berkualitas.

Dalam melakukan pemasaran lele dan olahannya harus memiliki jaringan (link) dengan komunitas dan masyarakat sehingga informasi terkait produk dapat disebarluaskan melalui komunitas dan pengguna (masyarakat).

\section{KESIMPULAN}

Pelaksanaan kegiatan pengabdian kepada masyarakat untuk para peternak dan calon peternak ikan lele di wilayah desa Cijayati, Bogor, telah memberikan pengetahuan dan pemahaman mengenai bentuk olahan dari ikan lele dan cara memasarkannya. Kegiatan ini bertujuan secara khusus untuk meningkatkan ekonomi rumah tangga dan secara umum ekonomi masyarakat.

\section{SARAN}

Kegiatan ini diharapkan akan berlanjut dalam kegiatan terkait pengembangan SDM dan teknologi pemasaran ikan lele dengan dukungan dari aparat desa, praktisi dan masyarakat.

\section{UCAPAN TERIMA KASIH}

Penulis mengucapkan terima kasih kepada P3M yang telah memberi dukungan berupa biaya terhadap keberhasilan pengabdian ini.

\section{REFERENSI}

Rachmatun Suyanto, 2010, Budidaya Ikan Lele (ed. Revisi), Penebar Swadaya, Jakarta ISBN : 9790021852.

Murniyati, Th. Dwi Suryaningrum, Ijah Muljanah, 2014, Membuat Fillet Lele dan Produk Olahannya, www.ternaklelesangkuriang.com, diunduh Juli 2017 